\title{
Pengaruh Pendekatan Matematika Realistik terhadap Motivasi dan Prestasi Belajar Siswa SD
}

\author{
Novia Dwi Wahyuni ${ }^{1} *$, J. Jailani ${ }^{1}$ \\ Univeristas Negeri Yogyakarta. Jalan Colombo No 1, Karangmalang, Yogyakarta, 55281, Indonesia \\ * Corresponding Author. Email: aisiteruphia@gmail.com \\ Received: 7 January 2016; Revised:23 June 2016; Accepted: 5 June 2017
}

\begin{abstract}
Abstrak
Penelitian ini bertujuan untuk mendeskripsikan pengaruh pembelajaran matematika dengan menggunakan pendekatan realistik terhadap motivasi belajar siswa di kelas dan pengaruh pembelajaran matematika dengan menggunakan pendekatan realistik terhadap prestasi belajar siswa. Penelitian ini merupakan penelitian eksperimen dengan desain pre-tes post-tes dengan kelompok nonekuivalen. Penelitian ini menggunakan kelompok eksperimen dan kelompok kontrol. Sampel penelitian ini adalah siswa kelas V SD Negeri Karangasem Yogyakarta dan SD Negeri Sarikarya Yogyakarta yang dipilih secara acak dengan teknik undian. Variabel bebas pendekatan pembelajaran, sedangkan variabel terikatnya adalah motivasi dan prestasi belajar. Teknik pengambilan data dilakukan dengan instrumen prestasi belajar siswa melalui pretest dan posttest. Data motivasi didapatkan menggunakan skala motivasi. Untuk membandingkan motivasi dan prestasi belajar siswa, data dianalisis dengan uji $t^{2}$-Hotelling's dan MANOVA. Hasil penelitian menunjukkan bahwa: (1) ada pengaruh yang signifikan antara pendekatan matematika realistik terhadap motivasi siswa pada taraf signifikansi sebesar $0,000<0,05 ;(2)$ ada pengaruh yang signifikan antara pendekatan matematika realistik terhadap prestasi belajar siswa pada tarafsignifikansi $0,042<0,05$.Perolehan gain untuk variabel motivasi dan prestasi pada kelas kontrol secara berturut-turut adalah 0,0045 dan 0,0897, sedangkan perolehan gain untuk variabel motivasi dan prestasi pada kelas eksperimen berturut-turut adalah 0,745 dan 0,434 .
\end{abstract}

Kata Kunci: matematika realistik, motivasi belajar, prestasi belajar

\section{The Effect of Using Realistic Mathematics on Motivation and Learning Achievement of Primary School Students}

\begin{abstract}
This study aims to find out (1) an effect of the realistic mathematics approach on the students' motivation, (2) an effect of the realistic mathematics approach on the students' achievement. This was a quasi-experimental study. The research employed the one group pretest-posttest design nonequivalent group. The research used to experiment class and control class. The sample comprised all grade 5 students of SD N Karangasem Yogyakarta and SD N Sarikarya Yogyakarta established using random sampling technique. The learning approach was the dependent variables, while motivation and achievement were the independent variables. The data were collected using a learning achievement test. The motivation data were collected using an achievement motivation scale. To compare the motivation and students' achievement, the data were analyzed using t2-Hotelling's and MANOVA. The result of the study shows that: (1) there is an effect of the realistic mathematics approach on the students' motivation at the significance level of $0.000<0.05$, (2) there is an effect of the realistic mathematics approach on the students' achievement at the significance level of $0.042<0.05$. The gain score of motivation and achievement in the control class are 0.0045 and 0.0897 , while the gain score of motivation and achievement in the experiment class are 0.745 and 0.434 .
\end{abstract}

Keywords: realistic mathematics, motivation, achievement

How to Cite: Wahyuni, N., \& Jailani, J. (2017). Pengaruh pendekatan matematika realistik terhadap motivasi dan prestasi belajar siswa SD. Jurnal Prima Edukasia, 5(2), 151-159. doi:http://dx.doi.org/10.21831/jpe.v5i2.7785

Permalink/DOI: http://dx.doi.org/10.21831/jpe.v5i2.7785

Copyright (C) 2017, Jurnal Prima Edukasia, ISSN: 2338-4743 (print), ISSN: 2460-9927 (online) 
Jurnal Prima Edukasia, 5 (2), July 2017 -152

Novia Dwi Wahyuni, J. Jailani

\section{Pendahuluan}

Rendahnya proses pembelajaran matematika pada umumnya hanya menekankan pada pencapaian target kurikulum dan penyampaian kontekstual semata, guru jarang memberi konteks untuk menghubungkan materi pelajaran dengan masalah nyata yang sering dihadapi siswa sehingga siswa kurang mampu memecahkan masalah matematika dalam kehidupan sehari-hari. Dalam proses pembelajaran masih sering ditemui fenomena kurangnya keterlibatan siswa. Guru mendominasi proses pembelajaran menyebabkan siswa cenderung lebih banyak menunggu penyajian guru daripada mencari dan menemukan sendiri pengetahuan dan keterampilan yang mereka butuhkan. Siswa hanya mengerjakan LKS (Lembar Kerja Siswa) saja tanpa ada pengarahan tentang materi yang diberikan. Kondisi seperti ini tidak akan menumbuhkembangkan potensi siswa seperti yang diharapkan sehingga hasil belajar siswa juga tidak optimal.

Siswa masih banyak mengalami kesulitan dalam pembelajaran matematika, diantaranya rendahnya motivasi siswa untuk mempelajari matematika. Hal ini tampak dari suasana pembelajaran di kelas seperti: siswa tidak memperhatikan apa yang disampaikan guru, kelas gaduh, kurang antusias dalam mengikuti pelajaran, dan banyak siswa yang tidak mau mengerjakan PR. Masalah lain diantaranya adalah kurangnya kemauan siswa untuk aktif mengerjakan soal sendiri, hal ini terlihat ketika diberikan soal untuk latihan, banyak siswa yang enggan mencoba sendiri dan menunggu bantuan dari guru. Selain itu, pendekatan matematika realistik belum diupayakan untuk diterapkan dalam pembelajaran matematika di SD N Karangasem Condongcatur Sleman.

Sardiman AM (2004, pp. 89-91) mengatakan bahwa motivasi dapat dibedakan menjadi dua macam yaitu : a) motivasi instrinsik dan b) motivasi ekstrinsik. Motivasi instrinsik adalah motivasi yang bersumber dari dalam diri siswa yang didasarkan kesadaran sendiri untuk melakukan sesuatu kegiatan belajar. Sedangkan motivasi ekstrinsik adalah motivasi yang datangnya dari luar diri siswa yang menyebabkan siswa tersebut melakukan kegiatan belajar.

Pritchard \& Woollard (2010, p. 14) berpendapat bahwa prestasi belajar merupakan hasil dari pengajaran yang lebih efektif dan pembelajaran yang dihasilkan dari tindakan positif guru dalam memberikan motivasi.
Hasil penelitian menunjukkan bahwa PMRI berpengaruh lebih besar terhadap kemampuan kognitif pada kemampuan mengaplikasikan dalam pembelajaran matematika SMP kelas VII (Widiyanti, 2012, p. 2). Senada dengan Penelitian yang dilakukan oleh Pamengkas bahwa Pendekatan realistik pada pelajaran matematika dapat meningkatkan keterlibatan siswa kelas III SDN Priyan Bantul (2011, p.2). Penelitian yang dilakukan oleh Zaini \& Marsigit(2014, p. 152) menunjukan bahwa (1)pembelajaran dengan pendekatan matematika realistik tidak efektif ditinjau dari kemampuan penalarantetapi efektif ditinjau dari kemampuan komunikasi matematika; (2) pembelajaran matematika dengan pendekatan konvensional tidak efektif ditinjau dari kemampuan penalaran dan komunikasi matematiksiswa; dan (3) pembelajaran pendekatan matematika realistik lebih baik dari pembelajaran konvensional ditinjau dari kemampuan penalaran dan komunikasi matematik siswa.

Penelitian yang dilakukan oleh Yudha \& Suwarjo (2014, p. 42) juga mengatakan bahwa PMR dapat meningkatkan kepercayaan diri dan hasil belajar siswa sekolah dasar. Senada dengan penelitian yang dilakukan oeh Widyastuti \& Pujiastuti (2014, p. 183) bahwa adanya pengaruh pembelajaran matematika dengan PMRI terhadap pemahaman konsep siswa dan berpikir logis siswa dari pada direct Instruction.

Dalam pembelajaran matematika realistik, titik mula pembelajaran haruslah nyata bagi siswa yang dapat mendorong siswa untuk terpaut dengan situasi tersebut. Prinsip-prinsip pendidikan matematika realistik (van den HeuvelPanhuizen, 2000, pp. 5-9) yaitu: (1) Activity principle,merupakan prinsip aktivitas yang menyatakan bahwa matematika adalah aktivitas manusia yaitu matematika yang paling baik dipelajari dengan melakukan, (2) Reality principle, merupakan prinsip realitas yang mana pembelajaran dimulai dari dunia nyata dan akan kembali lagi ke dunia nyata, (3) Level principle, merupakan prinsip penjenjangan yang menyatakan bahwa pemahaman siswa dimulai dari beberapa jenjang, mulai dari menemukan penyelesaian masalah kontekstual secara informasi ke skematis, ke pemerolehan insight terus ke penyelesaian secara formal masalah matematika, (4) Intertwinment principle, meru-pakan prinsip jalinan yang menyatakan bahwa pembelajaran matematika adalah pembelajaran yang mengkaitkan matematika dengan bidang lain, (5) Interaction principle, merupakan prin-sip interaksi yang menyatakan bahwa belajar matema- 
Jurnal Prima Edukasia, 5 (2), July 2017 -153

Novia Dwi Wahyuni, J. Jailani

tika adalah aktivitas manusia yang juga dipandang sebagai aktivitas sosial, (6) Guidance principle, merupakan prinsip bimbingan dan menyatakan bahwa dalam menemukan kembali matematika, siswa masih membutuhkan bimbingan.

Menurut Frans Moerlands, (dalam Sugiman, 2011, p. 8) mendiskripsikan tipe realistik dalam ide gunung es (iceberg) yang mengapung di tengah laut. Dalam model gunung es terdapat empat tingkatan aktivitas, yakni (1) orientasi lingkungan secara matematis (2) model alat peraga, (3) Pembuatan pondasi (building stone)dan (4) matematika formal. Contoh ide gunung es untuk sifat asosiatif terhadap penjumlahan dapat dilihat pada Gambar 1 .

Tujuan dari penelitian ini adalah (1) Mendeskripsikan pengaruh pembelajaran matematika dengan menggunakan pendekatan realistik terhadap motivasi siswa di dalam kelas. (2) Mendeskripsikan pengaruh pembelajaran matematika dengan menggunakan pendekatan realistik terhadap prestasi belajar siswa.

\section{Metode}

Jenis penelitian ini berupa penelitian kuantitatif dengan menggunakan metode eksperimen semu atau sering disebut eksperimen kuasi (quasi eksperimental research).Jenis yang digunakan dalam penelitian ini adalah pretestpostes with nonequivalent group.

Penelitian ini dilaksanakan di SD N Karangasem Condongcatur Depok Sleman Yogyakarta dan SD N Sarikarya Depok Sleman Yogyakarta kelas V. SDN Karangasem sebagai kelas eksperimen dan SD N Sarikarya sebagai kelas kontrol dan dipilih secara acak. Waktu penelitian dilaksanakan pada semester I tahun ajaran 2014/2015 pada bulan November 2015 dengan pertemuan sebanyak 10 kali. Treatment atau pemberian perlakuan dilakukan oleh peneliti.

Populasi dalam penelitian ini adalah keseluruhan siswa kelas V SD di wilayah gugus VII Kecamatan Depok Kabupaten Sleman. Dari 20 SD yang ada dipilih dua SD secara acak dengan teknik undian untuk dijadikan sampel penelitian. Setelah itu terpilihlah sampel pada penelitian ini yaitu siswa kelas V SD N Karangasem yang merupakan kelas eksperimen.

Data yang dibutuhkan dalam penelitian ini adalah data tentang motivasi dan prestasi belajar siswa. Data motivasi belajar dikumpulkan dengan menggunakan skala motivasi, sedangkan data prestasi belajar menggunakan tes.

Alat ukur motivasi dibuat dengan menggunakan skala kategoris yang digunakan dalam hal ini sesuai dengan pendapat Donal Ary, et all dalam terjemahan Furchan (2011, p. 274) pada skala penilaian kategori ini digunakan untuk mengukur tingkah laku atau penampilan orang lain.

Setiap pernyataan dalam instrumen ini memiliki lima alternatif jawaban, yaitu Selalu (SL), Sering (SR), "Kadang-kadang (Kd), Jarang (Jr), dan Tidak Pernah(TP), dimana masingmasing jawaban tersebut memiliki nilai sendirisendiri, yang bergerak dari skor 1 sampai 5, sesuai dengan sifat favorable/unfavorable dari item pernyataannya.

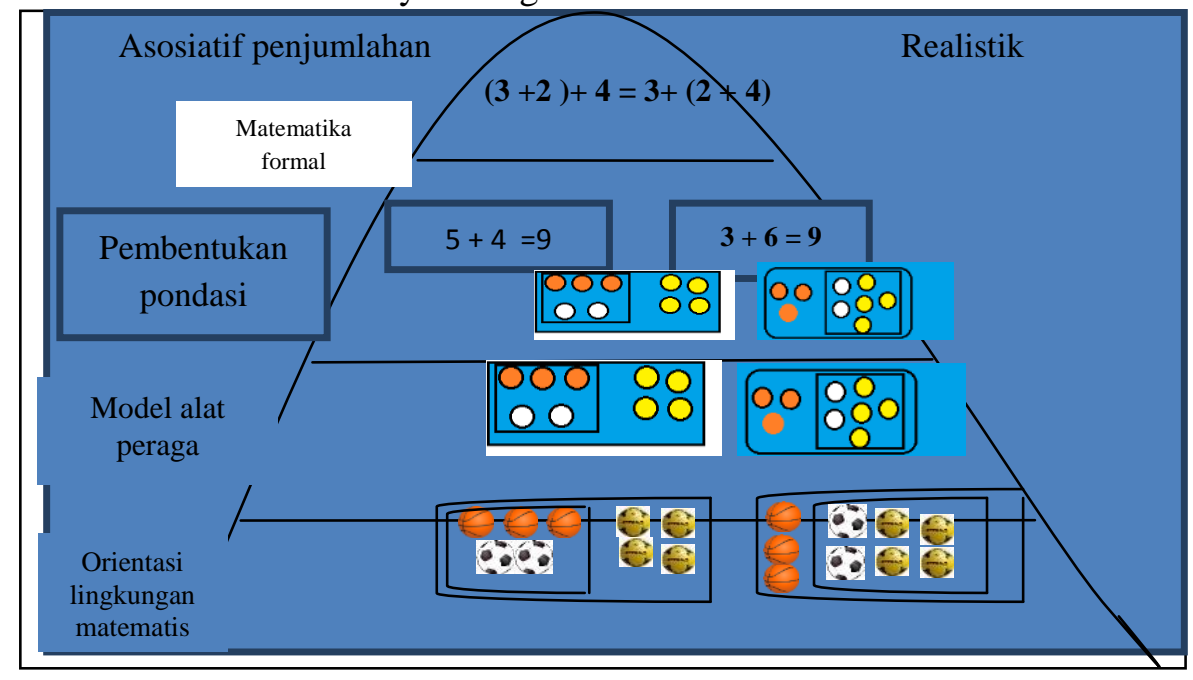

Gambar 1. Gunung Es Sifat Asosiatif terhadap Penjumlahan 
Tes prestasi belajar berbentuk tes objektif pilihan ganda dengan empat pilihan. Penyusunan tes prestasi mengacu pada teknik penyusunan tes objektif pilihan ganda Arikunto (2010, pp. 167-168) dan Mardapi (2004, pp. 88-95) yaitu (1) membuat kisi-kisi berdasarkan Kurikulum Tingkat Satuan Pendidikan mata pelajaran Matematika SD kelas V, materi pokok operasi hitung bilangan bulat, (2) membuat soal tes prestasi belajar aspek kognitif berdasarkan kisikisi yang telah dibuat dan membuat kunci jawaban, (3) penyusunan soal tes sesuai dengan proses pembelajaran di sekolah. Tes disusun berdasar kompetensi dasar yang tercermin dalam kelompok bahasan. Soal disusun sebanyak 30 butir soal. Materi tes pelajaran pada bidang studi matematika bagi siswa kelas $\mathrm{V}$ sesuai dengan standar isi pada Kurikulum Tingkat Satuan Pendidikan (KTSP) yaitu materi operasi hitung bilangan bulat, (4) meminta pertimbangan (judgement) kepada dua orang dosen dan satu guru bidang studi matematika terhadap instrumen penelitian, kemudian melakukan revisi soal berdasarkan bahan pertimbangan tersebut, (5) melakukan uji coba instrumen tes dan menganalisa butir soal, (6) melakukan analisis uji coba instrumen tes yang meliputi uji validitas, realibilitas, taraf kemudahan dan daya pembeda, (7) merakit tes.

Dalam mengembangkan tes dan angket, dilakukan uji validitas instrument.Penelitian ini menggunakan pengujian validitas isi dan konstruk dengan mengacu pada pendapat ahli (expert judgement). Penilaian terhadap validitas instrumen didasarkan pada pendapat ahli (expert judgement) pada penelitian ini, validator instrument adalah Dr. Sugiman dan Dr. Ali Mustadi, M.Pd. Setelah divalidasi maka instrument diujicobakan. Uji coba soal hasil belajar bilangan bulat dilakukan di SDN Karangasem kelas 6 dengan jumlah 30 orang dilakukan pada tanggal 8 November 2014.

Dalam penelitian ini, data yang dikumpulkan untuk dianalisis adalah data tentang motivasi dan prestasi belajar matematika siswa. Teknik analisis data menggunakan dua jenis statistik, yaitu statistik deskriptif dan statistik inferensial. Statistik deskriptif digunakan untuk menyajikan data yang telah diperoleh melalui hasil pre-test dan post-test variabel motivasi dan prestasi, baik pada kelompok eksperimen dan kelompok kontrol.

Dalam penelitian ini teknik analisis data yang digunakan adalah teknik analisis uji $t$ sampel bebas dan uji Manova. Uji $t$ sampel bebas digunakan untuk melihat apakah terdapat perbedaan yang signifikan antara rerata kelomok eksperimen dan kelompok kontrol, sedangkan uji Manova digunakan untuk melihat pengaruh pendekatan matematika realistik terhadap motivasi dan prestasi siswa. Perhitungan analisis yang digunakan adalah fasilitas SPSS 20 for windows.

Sebelum dilakukan hipotesis menggunakan uji $t$ sebelumnya dilakukan uji asumsi normalitas dan homogenitas. Selanjutnya, untuk uji Manova, terlebih dahulu diselidiki asumsi yang disyaratkan yaitu uji homogenitas varian dan uji homogenitas varian-covarian dengan menggunakan homogenitas Levene.

Uji normalitas yang digunakan dalam penelitian ini adalah uji Kolmogorov Smirnov dengan taraf signifikansi $5 \%$, perumusan hipotesisnya adalah $\mathrm{H}_{\mathrm{o}}=$ sampel berasal dari populasi yang berdistribusi normal dan $\mathrm{H}_{1}=$ sampel tidak berasal dari populasi yang berdistribusi normal.

Diambil $\alpha=0,05$ maka kriteria pengujiannya adalah Jika nilai signifikansi pengujiannya lebih besar atau sama dengan 0,05 maka $\mathrm{H}_{0}$ diterima atau jika nilai signifikansi pengujiannya lebih kecil dari 0,05 maka $\mathrm{H}_{0}$ ditolak.

Uji homogenitas yang digunakan dalam penelitian ini adalah uji levene dengan taraf signifikansi 5\%. Dengan menggunakan $\alpha=0,05$ hipotesisnya adalah $\mathrm{H}_{\mathrm{o}}=$ varian variabel adalah sama dan $\mathrm{H}_{1}$ = varian variabel tidak sama, maka kriteria pengujiannya adalah jika nilai signifikansi pengujiannya lebih besar atau sama dengan 0,05 maka $\mathrm{H}_{0}$ diterima atau jika nilai signifikansi pengujiannya lebih kecil dari 0,05 maka $\mathrm{H}_{0}$ ditolak.

Selanjutnyaadalahujiasumsi MANOVA yaitu dalam uji homogenitas varian, peneliti menggunakan metode Levene dengan bantuan program SPSS 20 for windows. Sedangkan untuk uji homogenitas varians-covarian, peneliti menggunakan metode Box's test. $\mathrm{H}_{0}$ diterima jika nilai sign lebih besar dari alpha yang ditetapkan 5\%. Sebaiknya, apabila nilai sign yang diperoleh dari alpha yang ditetapkan, maka $\mathrm{H}_{0}$ ditolak. Hipotesis penelitiannya adalah:

Hipotesis 1

$\mathrm{H}_{0}$ : tidak terdapat perbedaan rerata motivasi belajar siswa yang mengikuti pembelajaran dengan pendekatan matematika realistik dan konvensional

$\mathrm{H}_{1}$ : terdapat perbedaan rerata motivasi belajar siswa yang mengikuti pembelajaran dengan 
Jurnal Prima Edukasia, 5 (2), July 2017 -155

Novia Dwi Wahyuni, J. Jailani

pendekatan matematika realistik dan konvensional

Hipotesis 2

$\mathrm{H}_{0}$ : tidak terdapat perbedaan rerata prestasi belajar siswa yang mengikuti pembelajaran dengan pendekatan matematika realistik dan konvensional

$\mathrm{H}_{1}$ : terdapat perbedaan rerata prestasi belajar siswa yang mengikuti pembelajaran dengan pendekatan matematika realistik dan konvensional

Secara statistik, hipotesisnya dapat disimbolkan sebagai berikut.

Hipotesis 1:

$\mathrm{H}_{0}: \mu_{m r}=\mu_{m k}$

$\mathrm{H}_{1}: \mu_{m r} \neq \mu_{m k}$

Hipotesis 2:

$\mathrm{H}_{0} \quad: \mu_{p r}=\mu_{p k}$

$\mathrm{H}_{1} \quad: \mu_{p r} \neq \mu_{p k}$
Hasil dan Pembahasan

Hasil

Data motivasi belajar siswa diperoleh dari lembar angket yang diisi oleh siswa pada pertemuan pertama dan pertemuan keenam. Penilaian motivasi belajar siswa mencakup motivasi instrinsik dan motivasi ekstrinsik. Berikut disajikan perbandingan skor dari pre-test dan post-test motivasi belajar pada kelom-pok realistik dan konvensional.

Tabel 2 dapat dilihat bahwa skor motivasi intrinsik lebih rendah daripada skor motivasi ekstrinsik. Terlihat juga bahwa skor motivasi untuk pre-test lebih rendah daripada skor motivasi untuk post-test. Rata-rata skor pre-test ke post-test kelas eksperimen mengalami kenaikan lebih besardari kelas kontrol. Sehingga dapat disimpulkan bahwa motivasi ekstrinsik lebih tinggi dibandingkan motivasi intrinsik pada pendekatan dengan menggunakan matematika realistik.

Tabel 2. Deskripsi Data Hasil Motivasi Belajar Siswa Kelas Eksperimen dan Kelas Kontrol Sebelum dan Sesudah Pembelajaran

\begin{tabular}{|c|c|c|c|c|c|}
\hline & \multirow{2}{*}{\multicolumn{2}{|c|}{ Motivasi Belajar }} & \multicolumn{3}{|c|}{ Deskripsi Data } \\
\hline & & & Rata-rata & Skor min & Skor mak \\
\hline \multirow{6}{*}{ Eks } & \multirow{3}{*}{ pre-test } & Internal & 34.79 & 23 & 46 \\
\hline & & Eksternal & 37.59 & 38 & 49 \\
\hline & & Total & 72.38 & 61 & 95 \\
\hline & \multirow{3}{*}{ post-test } & Internal & 43.26 & 28 & 60 \\
\hline & & Eksternal & 50.26 & 33 & 66 \\
\hline & & Total & 93.52 & 61 & 126 \\
\hline \multirow{6}{*}{ Kontrol } & \multirow{3}{*}{ pre-test } & Internal & 35.87 & 24 & 48 \\
\hline & & Eksternal & 39 & 25 & 55 \\
\hline & & Total & 74.87 & 49 & 103 \\
\hline & \multirow{3}{*}{ post-test } & Internal & 34.6 & 21 & 50 \\
\hline & & Eksternal & 43.5 & 29 & 61 \\
\hline & & Total & 78.1 & 50 & 111 \\
\hline
\end{tabular}

Tabel 3. Deskripsi Data Hasil Tes Prestasi Belajar Matematika Pretest dan Posttest

\begin{tabular}{|c|c|c|c|c|}
\hline \multirow{2}{*}{ Deskripsi } & \multicolumn{2}{|c|}{ Kelas Eksperimen } & \multicolumn{2}{|c|}{ Kelas kontrol } \\
\hline & pre-test & post-test & pre-test & post-test \\
\hline Nilai rata-rata & 56,68 & 75,47 & 65,43 & 68,53 \\
\hline Standar deviasi & 18,01 & 13,11 & 15,28 & 13,62 \\
\hline Nilai maksimum & 88 & 100 & 88 & 85 \\
\hline Nilai minimum & 21 & 54 & 21 & 42 \\
\hline
\end{tabular}

Tabel 4. Rangkuman Uji Normalitas Kelompok Eksperimen dan Kontrol

\begin{tabular}{ccllll}
\hline No. & Instrumen & \multicolumn{1}{c}{ Perlakuan } & \multicolumn{1}{c}{ Kelas } & Ket \\
\hline 1. & Motivasi & pre-test & Eksperimen & 0,200 & Normal \\
2. & & & Kontrol & 0,200 & Normal \\
3. & & post-test & Eksperimen & 0,200 & Normal \\
4. & & Kontrol & 0,200 & Normal \\
5. & Prestasi & pre-test & Eksperimen & 0,200 & Normal \\
6. & & & Kontrol & 0,111 & Normal \\
7. & & post-test & Eksperimen & 0,130 & Normal \\
8. & & Kontrol & 0,151 & Normal \\
\hline
\end{tabular}


Jurnal Prima Edukasia, 5 (2), July 2017 -156

Novia Dwi Wahyuni, J. Jailani

Selanjutnya Tabel 3 menyajikan hasil tes prestasi belajar siswa pada kedua kelompok. Berdasarkan analisis deskripsi prestasi belajar siswa terhadap pembelajaran matematika, menunjukkan rata-rata pre-test prestasi belajar kelas eskperimen adalah 56,68 dan untuk kelas kontrol adalah 65,43 . Nilai minimum prestasi pada kelas eksperimen dan kontrol adalah 21 . Nilai maksimum prestasi pada kelas eksperimen dan kontrol adalah 88. Dapat dikatakan bahwa pendekatan matematika realistik lebih meningkatkan prestasi belajar daripada pendekatan konvensional.

Uji asumsi t test meliputi uji normalitas dan uji homogenitas. Uji normalitas bertujuan untuk mengetahui apakah subjek penelitian berasal dari populasi yang berdistribusi normal. Dalam melakukan uji normalitas ini, peneliti menggunakan metode Kolmogorov-Smirnov dengan bantuan program SPSS 20 for windows. Adapun hipotesis yang diajukan adalah sebagai berikut:

Uji Normalitas

$\mathrm{H}_{0}$ : Data berdistribusi normal

$\mathrm{H}_{\mathrm{a}}$ : Data berdistribusitidak normal

Berdasarkan hasil perhitungan dengan program SPSS 20 for windows, tampak nilai signifikansi lebih besar pada tingkat $\alpha$ yang digunakan $(\alpha=0,05)$ sehingga $\mathrm{H}_{0}$ diterima. Artinya variabel motivasi dan prestasi belajar yang diteliti mengikuti distribusi normal.

Uji Homogenitas

$\mathrm{H}_{0}$ : Varian variabel bersifat homogen

$\mathrm{H}_{\mathrm{a}}$ : Varian variabel bersifat heterogen

Tabel 5. Rangkuman Uji Homogenitas Kelas Eksperimen dan Kelas Kontrol

\begin{tabular}{clcl}
\hline No. & \multicolumn{1}{c}{ Instrumen } & Sign. & Ket. \\
\hline 1. & Motivasi pre-test & 0,072 & Homogen \\
2. & Motivasi post-test & 0,846 & Homogen \\
3. & Prestasi pre-test & 0,174 & Homogen \\
4. & Prestasi post-test & 0,869 & Homogen \\
\hline
\end{tabular}

Berdasarkan hasil perhitungan dengan program SPSS 20 for windows, tampak nilai signifikansi lebih besar pada tingkat $\alpha$ yang digunakan $(\alpha=0,05)$ sehingga $\mathrm{H}_{0}$ diterima. Artinya skor-skor variabel motivasi dan skorskor prestasi menyebar secara homogen.

\section{Uji Asumsi MANOVA}

Uji normalitias multivariat dihitung dengan bantuan SPSS 20 for windows.
Tabel 6. Hasil Uji Normalitas Multivariat

\begin{tabular}{clll}
\hline Deskripsi & Sig & N & Korelasi \\
Motivasi dan prestasi belajar & 0,12 & 64 & 0,998 \\
\hline
\end{tabular}

Berdasarkan Tabel 6, nilai sig 0,12>0,05 maka data berdistibusi normal secara multivariat.

Selanjutnya dilakukan uji homogenitas varian dan uji homogenitas varian-covarian. Dalam melakukan uji homogenitas varian, peneliti menggunakan metode Lavene dengan bantuan program SPSS 20 for windows. Sedangkan untuk uji homogenitas varians-covarian, peneliti menggunakan metode Box's M test. Berikut adalah hipotesis yang diajukan.

Uji Homogenitas Varian

$\mathrm{H}_{0}$ : Varian variable bersifat homogen $\mathrm{H}_{1}$ : Varian variable bersifat heterogen

Tabel 7. Rangkuman Uji Homogenitas Varian

\begin{tabular}{ccccc}
\hline Instrumen & F & df1 & df2 & sign \\
\hline Motivasi & 0,038 & 1 & 62 & 0,846 \\
Prestasi & 0,028 & 1 & 62 & 0,869 \\
\hline
\end{tabular}

Apabila nilai sign lebih besar dari alpha yang ditetapkan 5\%, maka $\mathrm{H}_{0}$ diterima. Sebaiknya, apabila nilai sign yang diperoleh dari alpha yang ditetapkan, maka $\mathrm{H}_{0}$ ditolak. Hasil dari uji homogenitas terhadap variabel motivasi dan prestasi belajar pada kelas kontrol dan eksperimen lebih besar dari 5\%. Hal ini berarti kedua kelompok memiliki varian yang sama.

Uji Homogenitas Varian-Covarian

$\mathrm{H}_{0}$ : Matriks varian-covarian dari variabel dependen adalah sama

$\mathrm{H}_{1}$ : Matriks varian-covarian dari variabel dependen adalah tidak sama

Tabel 8. Uji Varian-Covarian

\begin{tabular}{lcccc}
\hline Box's M & F & df1 & df2 & Sign. \\
\hline 0,218 & 0,70 & 3 & 1457652,64 & 0,976 \\
\hline
\end{tabular}

Apabila nilai signifikansi yang diperoleh lebih besar dari alpha $5 \%$ maka $\mathrm{H}_{0}$ diterima. Sebaliknya, apabila nilai signifikansi yang diperoleh lebih kecil dari alpha maka $\mathrm{H}_{0}$ ditolak. Hasil uji homogenitas terhadap variabel motivasi dan prestasi belajar pada kelas kontrol dan eksperimen adalah lebih dari 5\% yaitu 0,976. Artinya bahwa matriks varian-covarian dari variabel dependen adalah sama. 


\section{Uji Hipotesis}

Uji hipotesis yang akan diuji adalah sebagai berikut.

$\mathrm{H}_{0}: \mu_{m r}=\mu_{m k}$ (tidak terdapat perbedaan rerata motivasi belajar siswa yang mengikuti pembelajaran dengan pendekatan matematika realistic dan konvensional)

$\mathrm{H}_{1}: \mu_{m r} \neq \mu_{m k}$ (terdapat perbedaan rerata motivasi belajar siswa yang mengikuti pembelajaran dengan pendekatan matematika realistik dan konvensional)

Untuk menguji ada tidaknya perbedaan motivasi belajar siswa kelas V SD pada mata pelajaran matematika, peneliti menggunakan independent sample t-test dengan bantuan program SPSS 20 for windows. Apabila nilai dignifikansi yang diperoleh $>5 \%$, maka $\mathrm{H}_{0}$ diterima. Sebaliknya apabila signifikansi $<5 \%$, maka $\mathrm{H}_{0}$ ditolak. Berikut disajikan data hasil uji $\mathrm{t}$ terhadap skor post-test.

Tabel 9. Uji t terhadap Skor Post-test Motivasi Belajar

\begin{tabular}{cccc}
\hline Instrumen & t & df & Sign. \\
\hline Motivasi & $-4,259$ & 62 & 0,000 \\
\hline
\end{tabular}

Dari Tabel 9 diperoleh nilai sign. sebesar 0,000 lebih kecil dari alpha yang ditetapkan, maka $\mathrm{H}_{0}$ ditolak. Oleh karena itu, dapat disimpulkan bahwa terdapat perbedaan motivasi belajar siswa yang signifikan antara kelas dengan pendekatan matematika realistik dengan pendekatan konvensional.

$\mathrm{H}_{0}: \mu_{p r}=\mu_{p k}$ (tidak terdapat perbedaan rerata prestasi belajar siswa yang mengikuti pembelajaran dengan pendekatan matematika realistik dan konvensional)

$\mathrm{H}_{1}: \quad \mu_{p r} \neq \mu_{p k} \quad$ (terdapat perbedaan rerata prestasi belajar siswa yang mengikuti pembelajaran dengan pendekatan matematika realistik dan konvensional)

Untuk menguji ada tidaknya perbedaan pestasi belajar siswa kelas V SD mata pelajaran matematika, peneliti menggunakan independent sample t-test dengan bantuan program SPSS 20 for windows. Apabila nilai signifikansi yang diperoleh > 5\%, maka $\mathrm{H}_{0}$ diterima. Sebaliknya, apabila nilai signifikansi $<5 \%$, maka $\mathrm{H}_{0}$ ditolak. Hasil analisis data uji t terhadap skor post-tes prestasi belajar terdapat pada Tabel 10 .

Tabel 10. Uji t terhadap Skor Post-test Prestasi Belajar

\begin{tabular}{cccc}
\hline Instrumen & $\mathbf{t}$ & $\mathbf{d f}$ & Sign (2-tailed) \\
\hline Prestasi & $-2,072$ & 62 & 0,042 \\
\hline
\end{tabular}

Dari Tabel 10 diperoleh nilai sign. sebesar 0,042 lebih kecil dari alpha yang ditetapkan, maka $\mathrm{H}_{0}$ ditolak. Oleh karena itu, dapat disimpulkan bahwa terdapat perbedaan prestasi belajar siswa yang signifikan antar kelas yang menggunakan pendekatan matematika realistik dengan pendekatan konvensional.

Rerata Gain

Untuk mengetahui tentang peningkatan skor, maka peneliti menggunakan rerata gain ternormalisasi (average normalized gain) dengan rumus sebagai berikut.

$(g)=\frac{\%(G)}{\%(G)_{\text {maks }}}=\frac{\left(\%\left(s_{f}\right)-\%\left(s_{i}\right)\right)}{\left(100-\%\left(s_{i}\right)\right)}$

Berdasarkan perhitungan tersebut, maka peneliti merangkum hasil perolehan gain kedua kelompok pada Tabel 11.

Tabel 11. Hasil Perolehan Gain

\begin{tabular}{ccc}
\hline Variabel & Kelas kontrol & Kelas eksperimen \\
\hline Motivasi & 0,0045 & 0,745 \\
Prestasi & 0,0897 & 0,434 \\
\hline
\end{tabular}

Berdasarkan Tabel 11 dapat diketahui perolehan gain untuk variabel motivasi dan prestasi pada kelas kontrol secara berturut-turut adalah 0,0045 dan 0,0897. Sedangkan perolehan gain untuk variabel motivasi dan prestasi pada kelas eksperimen berturut-turut adalah 0,745 dan 0,434. Berdasarkan data perbandingan peningkatan rerata gain skor kedua kelompok eksperimen mengalami peningkatan rerata skor yang lebih tinggi dibandingkan kelompok kontrol.

Selanjutnya akan diklasifikasikan masingmasing perolehan gain skor, peneliti membandingkan dengan kriteria perolehan gain skor disajikan pada tabel berikut.

Tabel 12. Kategori Perolehan Gain Skor

\begin{tabular}{cc}
\hline Kriteria & Keterangan \\
\hline$(\mathrm{g}) \geq 0,7$ & Tinggi \\
$0,7>(\mathrm{g}) \geq 0,3$ & Sedang \\
$(\mathrm{g})<0,3$ & Rendah \\
\hline
\end{tabular}

Berdasarkan Tabel 12, perolehan gain dapat disimpulkan bahwa peningkatan rerata gain skor untuk variabel motivasi dan prestasi belajar siswa tergolong tinggi untuk motivasi eksperimen, tergolong sedang untuk prestasi eksperimen, dan tergolong rendah untuk motivasi dan prestasi kontrol.

Untuk menguji apakah penerapan pendekatan matematika realistik berpengaruh secara 
Jurnal Prima Edukasia, 5 (2), July 2017 -158

Novia Dwi Wahyuni, J. Jailani

signifikan terhadap motivasi dan prestasi belajar siswa pada mata pelajaran matematika, digunakan uji multivariat yaitu Hotelling's Trace. Berikut adalah hasil uji multivariat.

Tabel 13. Uji Multivariat

\begin{tabular}{cccc}
\hline & value & F & Sign. \\
\hline Hotelling's Trace & 0,34 & 10.41 & 0,000 \\
\hline
\end{tabular}

Berdasarkan Tabel 13 diketahui nilai $\mathrm{F}$ test Hotelling's Trace sebesar 10.413 dengan nilai signifikansi sebesar 0,0000 . Nilai signifikansi lebih kecil dari alpha 0,05. Artinya dapat disimpulkan bahwa pendekatan matematika realistik berpengaruh secara positif dan signifikan terhadap motivasi dan prestasi belajar siswa.

Pembahasan

Berdasarkan kesimpulan dari Tabel 9, Tabel 11, Tabel 12 untuk perhitungan data motivasi melalui uji statistik, menunjukkan adanya peningkatan antara sebelum dengan sesudah pembelajaran menggunakan pendekatan matematika realistik pada kelompok eksperimen dan kelompok kontrol yang menggunakan pendekatan konvensional. Seperti pendapat Santrock (2010, p. 510) tentang motivasi merupakan proses yang memberi semangat, arah, dan kegigihan perilaku. Dalam pembelajaran motivasi murid di kelas berkaitan dengan alasan di balik perilaku mereka dan sejauh mana perilaku mereka jika diberi semangat, punya arah dan dipertahankan dalam jangka waktu yang lama.

Peningkatan prestasi belajar ditunjukkan oleh kelompok eksperimen dan kelompok kontrol tidak lepas dari keterlibatan beberapa faktor, baik itu faktor internal maupun eksternal dari suatu pembelajaran. Salah satu faktor tersebut adalah kemampuan guru dalam menyampaikan pelajaran dengan efektif dan efisien. Untuk itu seorang guru harus mengenal berbagai strategi agar proses pembelajaran itu menarik sehingga siswa lebih termotivasi untuk belajar lebih giat.Seperti pendapat Slavin \& Samosir (2009, p. 106) bahwa tugas penting bagi guru adalah merencanakan bagaimana mereka nantinya mendukung motivasi siswa.

Penelitian ini dapat menunjukkan bahwa pembelajaran yang menggunakan pendekatan matematika realistik menghasilkan peningkatan motivasi dan prestasi belajar yang lebih tinggi pada kompetensi dasar operasi bilangan bulat jika dibandingkan dengan pembelajaran menggunakan pendekatan konvensional. Dengan demikian penggunaan pendekatan matematika realistik dapat meningkatkan prestasi belajar siswa, karena siswa berperan aktif dalam kesuksesan pembelajaran, ia tidak berposisi sebagai objek, tetapi juga sebagai subjek pada dirinya sendiri.Seperti pendapat Romberg \& Shafer (2008, pp. 16-17), bahwa prestasi belajar sebagai penguasaan pengetahuan atau keterampilan yang dikembangkan melalui mata pelajaran, lazimnya ditujukan dengan nilai tes atau angka yang diberikan oleh guru. Dengan adanya pendekatan matematika realistik dapat menjadi acuan oleh guru dalam menyampaikan materi operasi hitung bilangan bulat. Sehingga siswa tidak menjadi pasif dan hanya mendengarkan materi yang diajarkan, tetapi juga berperan aktif dalam proses pembelajaran.

Penyajian dalam pendekatan matematika realistik merupakan model pendekatan pembelajaran yang ideal, karena menekankan pembelajaran yang dimulai dari lingkungan yang nyata. Pendekatan pembelajaran ini juga efektif karena, yang pada akhirnya akan dapat meningkatkan hasil belajar siswa secara signifikan. Dalam pembelajaran matematika realistik, titik mula pembelajaran haruslah nyata bagi siswa yang dapat mendorong siswa untuk terpaut dengan situasi tersebut. Sehingga akan memudahkan siswa untuk mengerti masalah matematika dalam kehidupannya nyata dan siswa dapat mengerjakan masalah matematika yang formal.

Dalam pembelajaran motivasi murid di kelas berkaitan dengan alasan di balik perilaku mereka dan sejauh mana perilaku mereka jika diberi semangat, punya arah dan dipertahankan dalam jangka waktu yang lama.

\section{Simpulan}

Berdasarkan hasil analisis data dan pembahasan, dapat disimpulkan sebagai bahwa pembelajaran matematika dengan menggunakan pendekatan realistik berpengaruh ditinjau dari motivasi belajar siswa kelas V SD N Karangasem Depok Sleman tahun pelajaran 2014/2015, dan pembelajaran matematika dengan menggunakan pendekatan realistik berpengaruh ditinjau dari prestasi belajar siswa kelas V SD N Karangasem Depok Sleman tahun pelajaran 2014/2015.

Saran-saran sebagai berikut: (1) Para guru matematika dalam penerapan pembelajaran matematika realistik disarankan agar lebih dapat memberikan kesempatan kepada siswa untuk menggali kemampuan dalam menyelesaikan masalah. Dalam hal ini sangat perlu dipersiapkan LKS realistik yang benar-benar dapat menuntun 
siswa dalam membangun pengetahuannya tanpa banyak penyelesaian dari guru, (2) Bagi peneliti, disarankan agar mengadakan penelitian untuk materi yang lebih berbeda dan kelas yang berbeda pula, (3) Demikian saran dari penelitian yang diharapkan dapat membuka tabir masalahmasalah yang tersirat dalam penelitian ini namun belum sepenuhnya dapat dijelaskan.

\section{Daftar Pustaka}

Arikunto, S. (2010). Prosedur penelitian: Suatu pendekatan praktik. Jakarta: Rineka Cipta.

Furchan, A. (2011). Pengantar penelitian dalam pendidikan. Yogyakarta: Pustaka Pelajar.

Mardapi, D. (2004). Penyusunan tes hasil belajar. Yogyakarta: Program Pascasarjana Universitas Negeri Yogyakarta.

Pritchard, A. M., \& Woollard, J. (2010). Psychology for the classroom: Constructivism and social learning. New York: Routledge.

Romberg, T. A., \& Shafer, M. C. (2008). The impact of reform instruction on student mathematics achievement. New York, NY: $\quad$ Routledge. https://doi.org/10.4324/9780203895221

Santrock, J. (2010). Educational psychology. handbook of educational psychology. https://doi.org/10.1146/annurev.ps.05.020 154.002041

Sardiman AM. (2004). Interaksi dan motivasi belajar mengajar. Depok: Rajagrafindo Persada.

Slavin, R., \& Samosir, M. (2009). Psikologi pendidikan: Teori dan praktik (Edisi Kedelapan) Jilid 2. Jakarta: PT Indeks.

Sugiman, S. (2011). Peningkatan pembelajaran matematika dengan menggunakan pendekatan matematika realistik.

Yogyakarta. Retrieved from http://staff.uny.ac.id/sites/default/files/tm p/2011_PPM_Iceberg_0.pdf

van den Heuvel-Panhuizen, M. (2000). Mathematics education in the Netherlands: A guided tour. In Freudenthal Institute Cd-rom for ICME9 (p. 32). Utrecht: Utrecht University. Retrieved from http://www.fisme.science.uu.nl/staff/marj ah/documents/TOURdef+ref.pdf

Widiyanti, R. A. (2012, October 31). Pengaruh pendekatan pendidikan matematika realistik indonesia (PMRI) dalam pembelajaran matematika terhadap kemampuan kognitif siswa SMP kelas VII. Universitas Negeri Yogyakarta. Retrieved from http://eprints.uny.ac.id/35419/

Widyastuti, N. S., \& Pujiastuti, P. (2014). Pengaruh pendidikan matematika realistik indonesia (PMRI) terhadap pemahaman konsep dan berpikir logis siswa. Jurnal Prima Edukasia, 2(2), 183. https://doi.org/10.21831/jpe.v2i2.2718

Yudha, C. B., \& Suwarjo, S. (2014). Peningkatan kepercayaan diri dan proses belajar matematika menggunakan pendekatan realistik pada siswa sekolah dasar. Jurnal Prima Edukasia, 2(1), 42. https://doi.org/10.21831/jpe.v2i1.2643

Zaini, A., \& Marsigit, M. (2014). Perbandingan keefektifan pembelajaran matematika dengan pendekatan matematika realistik dan konvensional ditinjau dari kemampuan penalaran dan komunikasi matematik siswa. Jurnal Riset Pendidikan Matematika, $\quad 1(2), \quad 152$. https://doi.org/10.21831/jrpm.v1i2.2672 